\title{
ACTIVATION OF $\beta_{2}$-ADRENERGIC RECEPTORS ON MOUSE ANTERIOR PITUITARY TUMOR CELLS INCREASES CYCLIC ADENOSINE $3^{\prime}: 5^{\prime}$-MONOPHOSPHATE SYNTHESIS AND ADRENOCORTICOTROPIN RELEASE ${ }^{1}$
}

\author{
TERRY D. REISINE, ${ }^{2}$ SEYMOUR HEISLER, ${ }^{*, 3}$ VIVIAN Y. H. HOOK, AND JULIUS AXELROD
}

Section on Pharmacology, Laboratory of Clinical Science, National Institute of Mental Health, Bethesda, Maryland 20205 and ${ }^{*}$ Unite de Bioregulation Cellulaire et Moleculaire, Centre Hospitalier de l'Université Laval, Quebec, Canada GIV 462

Received July 12, 1982; Revised October 28, 1982; Accepted November 10, 1982

\begin{abstract}
AtT-20 cells comprise a mouse anterior pituitary tumor cell line that synthesizes and secretes adrenocorticotropin hormone (ACTH). $\beta$-Adrenergic receptors were characterized on AtT-20 cells using receptor binding methodology and the ability of $\beta$-receptor agonists to stimulate intracellular cyclic adenosine $3^{\prime}: 5^{\prime}$-monophosphate (cAMP) formation and the release of ACTH immunoreactivity. The density of $\beta$-receptors on membrane preparations of these cells is $64 \mathrm{fmol} / \mathrm{mg}$ of protein and their affinity constant ( $K_{\mathrm{D}}$ value) for tritiated dihydroalprenolol is $11 \mathrm{nM}$. The binding of $\left[{ }^{3} \mathrm{H}\right]$ dihydroalprenolol to AtT-20 cells is stereoselectively inhibited by propranolol and isoproterenol but is not affected by phentolamine. The $\beta$-receptors on these cells appear to be of the $\beta_{2}$-receptor subtype since a selective $\beta_{2}$-receptor agonist, salmefamol, can inhibit $\left[{ }^{3} \mathrm{H}\right]$ dihydroalprenolol binding, whereas practolol, a $\beta_{1}$-receptor blocker, is ineffective. (-)-Isoproterenol stimulates cAMP formation in AtT-20 cells and this effect is blocked by $d l$-propranolol. Both $l$-epinephrine and $l$-norepinephrine induce dose-dependent increases in cAMP formation with the former agonist being more potent. Salmefamol also stimulates cAMP formation in these cells. The secretion of ACTH from AtT-20 cells is induced by (-)-isoproterenol as well as by other adrenergic agonists. The isoproterenol effect on ACTH release is stereoselective, calcium dependent, and blocked by $d l$-propranolol but not by phentolamine or practolol.
\end{abstract}

Adrenocorticotropin hormone $(\mathrm{ACTH})$ is synthesized and released from adenohypophyseal corticotropin cells. The secretion of this substance can be regulated by a number of different agents. A corticotropin-releasing factor (CRF) from ovine hypothalamus has recently been isolated and characterized (Spiess et al., 1981; Vale et al., 1981; River et al., 1982). There is evidence suggesting that catecholamines control ACTH release (Vale and Rivier, 1977). The peripheral administration of $l$-epinephrine increases ACTH-like immunoreactivity in the plasma (Berkenbosch et al., 1981; Tilders et al., 1982). This in vivo elevation of ACTH secretion is mimicked by $(-)$-isoproterenol and blocked by $l$-propranolol which would indicate that $\beta$-adrenergic receptors are involved in modulating ACTH release. Furthermore, activation of $\alpha_{1}$-adrenergic receptors in primary cultures of dispersed

\footnotetext{
${ }^{1}$ We would like to thank Ms. Sandy Derdeyn for her assistance in preparing the manuscript.

${ }^{2}$ To whom correspondence should be addressed.

${ }^{3}$ Visiting Scientist, Medical Rescarch Council of Canada.
}

anterior pituitary cells induced an increase in ACTH secretion (Vale and Rivier, 1977; Giguere et al., 1981, 1982a). However, no evidence is available concerning whether catecholamines can directly stimulate corticotrophs to secrete ACTH.

AtT-20 mouse pituitary tumor cells synthesize and secrete both ACTH and $\beta$-endorphin (Mains and Eipper, 1976, 1981; Eipper and Mains, 1980; Allen et al., 1978; Roberts and Herbert, 1977a, b; Roberts et al., 1978) and respond to synthetic CRF (Hook et al., 1982). Norepinephrine has also been found to stimulate ACTH release from these cells in a calcium-dependent manner (Mains and Eipper, 1981). In the present study we characterized $\beta_{2}$-adrenergic receptors on AtT-20 cells and showed that their activation increases intracellular AMP content and ACTH release.

\section{Materials and Methods}

Dulbecco's modified Eagle's Medium (DMEM) (4500 $\mathrm{mg} / \mathrm{ml}$ of glucose) and rabbit serum were obtained from Grand Island Biological Co. (Grand Island, NY). Fetal 
calf serum was from North American Biologicals (Miami, FL). Human ACTH (synthetic) and antiserum were gifts from the National Pituitary Agency (Baltimore, MD). ${ }^{125}$ I-labeled-human $\mathrm{ACl} H \mathrm{H}$ was from Immunonuclear Corp. (Stillwater, MN). Goat anti-rabbit immunoglobulin was from N. L. Cappel Laboratories Inc. (Cochranville, PA). Bacitracin, dexamethasone, barbital, human serum albumin, $(+)$ - or $(-)$-isoproterenol-(+)-bitartrate, $l$-epinephrine-(+)-bitartrate, 3-isobutyl-1-methylxanthine (IBMX), and $d l$ - and $d$-propranolol were from Sigma Chemical Co. (St. Louis, MO). Phentolamine hydrochloride was from Ciba-Geigy Corp. (Summit, $\mathrm{NJ}$ ). $d$ - and $l$ Norepinephrine- $d$-bitartrate were from Sterling-Winthrop Research Institute (Rensselaer, NY). $\left.{ }^{3} \mathrm{H}\right]$ Dihydroalprenolol $\left(\left[{ }^{3} \mathrm{H}\right] \mathrm{DHA}\right)(43 \mathrm{Ci} / \mathrm{mmol})$ and the cAMP immunoassay kits were from New England Nuclear, Boston, MA. Salmefamol and practolol were the generous gifts of Dr. Perry Molinoff, University of Pennsylvania, Philadelphia, PA. Verapamil was kindly provided by $\mathrm{H}$. E. Graham of Knoll Pharmaceutical Co. (Whippany, NJ). All other chemicals were of reagent grade.

\section{Cell culture techniques}

Mouse AtT-20/D16-16 tumor cells were grown and subcultured in DMEM with $10 \%$ fetal calf serum as previously described (Hook et al., 1982). Cells that were used for the cAMP and ACTH studies were plated in 35$\mathrm{mm}$ diameter culture cluster dishes (Costar) at an initial density of $1.5 \times 10^{5}$ cells/well and were used 5 to 7 days after subculturing (60 to $80 \%$ confluency). The cells used in the receptor-binding assays were plated in $75-\mathrm{cm}$ flasks (Costar) and also were used 5 to 7 days after subculturing.

\section{$\left[{ }^{3}\right.$ H]Dihydroalprenolol binding assay}

Tissue preparation. Plated cells initially were washed three times with phosphate-buffered saline (PBS) $(\mathrm{pH}$ 7.4) in order to remove fetal calf serum. Cells were detached from the flasks in PBS, pelleted and resuspended in $0.32 \mathrm{M}$ sucrose, homogenized with a Brinkman Polytron (setling, 5 or $10 \mathrm{sec}$ ) and centrifuged at 100,000 $\times g$ for $1 \mathrm{hr}$. The supernatant was removed and the pellet was either immediately frozen at $-20^{\circ} \mathrm{C}$ or resuspended in $50 \mathrm{~mm}$ Tris-HCl buffer ( $\mathrm{pH} 7.8)$, homogenized, and centrifuged again at $20,000 \times g$ for $20 \mathrm{~min}$. Following removal of the supernatant, the pellet was resuspended in Tris-HCl buffer and used in the binding assay.

Binding assay. In the $\left[{ }^{3} \mathrm{H}\right]$ dihydroalprenolol binding assay, the radioactive ligand at varying concentrations ( 1 to $25 \mathrm{~nm}$ ) was incubated with tissue (approximately 50 $\mu \mathrm{g}$ of protein) and various drugs in Tris- $\mathrm{HCl}$ buffer for 30 min at $25^{\circ} \mathrm{C}$. Total incubation volume was $0.2 \mathrm{ml}$. The reaction was terminated by vacuum filtration over Whatman GF/C glass fiber filters. The filters were washed four times (a total of $16 \mathrm{ml}$ ) with ice-cold buffer. The filters were then dried and placed in $10 \mathrm{ml}$ of Hydrofluor. Radioactivity was assessed by liquid scintillation spectrometry. Tissue-specific $\left[{ }^{3} \mathrm{H}\right] \mathrm{DHA}$ binding (displaced by $10 \mu \mathrm{M} d l$-propranolol) accounted for $70 \%$ of total tissue binding. Appreciable amounts (30\% of total filter binding) of non-tissue filter binding occurred which was not displaced by propranolol $(10 \mu \mathrm{M})$. Nonspecific, non-tissue binding was subtracted from total binding in calculating tissue-specific $\left[{ }^{3} \mathrm{H}\right] \mathrm{DHA}$ binding.

\section{Incubation procedures for ACTII and cAMP studies}

$A C T H$. Prior to the reactions, the culture medium was removed from the wells and $1 \mathrm{ml}$ of DMEM and HEPES (25 mM) with $2 \%$ fetal calf serum and $3 \mu \mathrm{g} / \mathrm{ml}$ of bacitracin were added. Cells were then equilibrated for $60 \mathrm{~min}$ and maintained at $37^{\circ} \mathrm{C}$ in an atmosphere of $5 \% \mathrm{CO}_{2}$. For the secretion studies, the equilibration medium was removed and similar medium containing various test agents was added. In experiments in which isoproterenol or catecholamines were used, $10 \mu \mathrm{M}$ ascorbic acid was present in the medium. Except for the time course studies, the reactants were usually incubated at $37^{\circ} \mathrm{C}$ for $60 \mathrm{~min}$. At the end of this time, samples $(0.6 \mathrm{ml})$ of medium were removed and centrifuged at $2000 \mathrm{rpm}$ for $1 \mathrm{~min}$, and a $0.4-\mathrm{ml}$ aliquot of the supernatant was frozen $\left(-20^{\circ} \mathrm{C}\right)$ for later ACTH analysis.

$c A M P$. Using a method similar to that of the ACTH studies, the cells were equilibrated for $60 \mathrm{~min}$ with $1 \mathrm{ml}$ of DMEM and HEPES with $2 \%$ fetal calf scrum and bacitracin $(3 \mu \mathrm{g} / \mathrm{ml})$. Then, $1 \mathrm{ml}$ of medium containing $0.5 \mathrm{~mm}$ IBMX was added to the cells for $30 \mathrm{~min}$. Following this preincubation period, $1 \mathrm{ml}$ of fresh medium containing test agents and $0.5 \mathrm{~mm}$ IBMX were added. Normally, incubations at $37^{\circ} \mathrm{C}$ were for $15 \mathrm{~min}$. The reaction was terminated by removal of the medium and the addition of ice-cold $10 \mathrm{~mm}$ acetic acid containing 0.5 mM IBMX to the cells. The plates were frozen and thawed to disrupt the cells. The cell fragments were dislodged from the plates with rubber policemen and collected along with the liquid solution. The samples were sonicated and $0.2-\mathrm{ml}$ portions were vacuum evaporated, resuspended in $50 \mathrm{~mm}$ sodium acetate buffer $(\mathrm{pH}$ 6.2), and analyzed for cAMP content.

$A C T H$ radioimmunoassay. ACTH immunoreactivity was measured as previously described (Hook et al., 1982). The antibody used was specific for the 14-24 segment of $\mathrm{ACTH}$. The results are expressed as nanograms of ACTH per well.

cAMP radioimmunoassay. cAMP levels were measured using the commercially available assay kit of New England Nuclear. Results are expressed as picomoles of cAMP formed per well. Values were not corrected for protein content since little variability in protein levels occurred between wells of each subculture.

\section{Results}

\section{$\left[{ }^{3} H\right]$ Dihydroalprenolol binding}

The $\beta$-adrenergic receptors on AtT-20 cell membranes were initially characterized using receptor-ligand binding techniques. The selective $\beta$-adrenergic receptor antagonist, $\left[{ }^{3} \mathrm{H}\right] \mathrm{DHA}$, was used to label $\beta$-receptors. Specific $\left[{ }^{3} \mathrm{H}\right] \mathrm{DHA}$ binding to AtT-20 cells (displaceable by $10 \mu \mathrm{M}$ $d l$-propranolol) accounted for $70 \%$ of total tissue binding. Specific binding was of high affinity and was saturable. Scatchard analysis of $\left[{ }^{3} \mathrm{H}\right] \mathrm{DHA}$ binding showed a straight line (Fig. 1). The density of $\beta$-receptors $\left(B_{\max }\right.$ value) was $64 \mathrm{fmol} / \mathrm{mg}$ of protein and the affinity of these sites ( $K_{\mathrm{D}}$ value) for $\left[{ }^{3} \mathrm{H}\right] \mathrm{DHA}$ was $11 \mathrm{nM}$. The binding of 


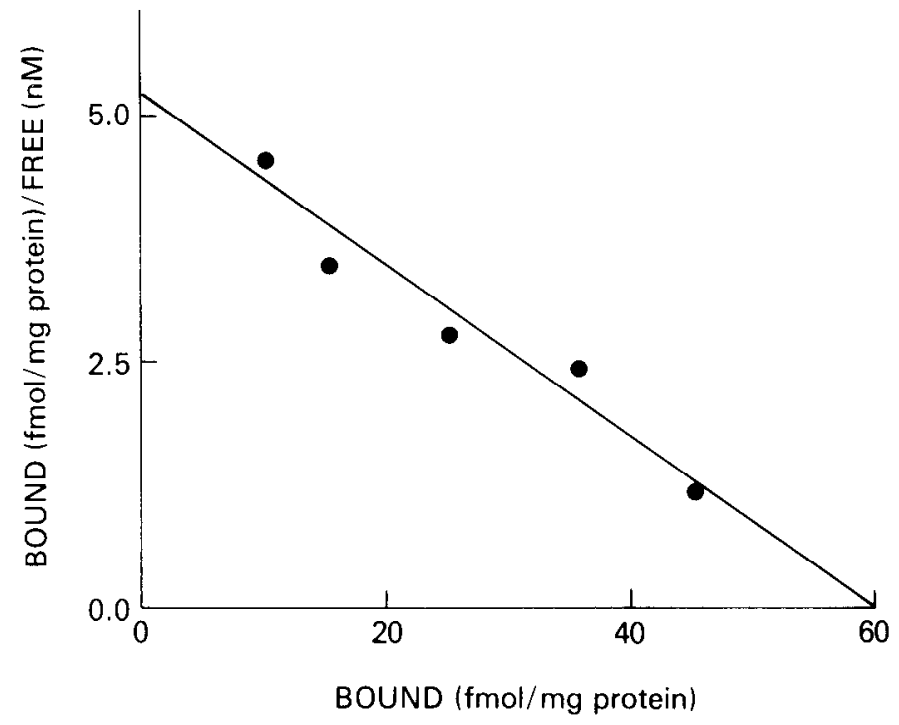

Figure 1. Scatchard plot of [ $\left.{ }^{3} \mathrm{H}\right] \mathrm{DHA}$ binding to AtT-20 cells. This analysis is a linearization of saturation isotherms derived from experiments in which varying concentrations of $\left[{ }^{3} \mathrm{H}\right] \mathrm{DHA}$ (1 to $25 \mathrm{nM}$ ) were incubated with homogenates of AtT-20 cells (approximately $50 \mu \mathrm{g}$ of protein) for $30 \mathrm{~min}$ at $25^{\circ} \mathrm{C}$. Specific binding was defined as that binding displaced by $10 \mu \mathrm{M} d l$ propranolol and accounted for $70 \%$ of total tissue binding. The maximum density of binding sites ( $B_{\max }$ value) as determined from the $x$ intercept was $64 \pm 8.9 \mathrm{fmol} / \mathrm{mg}$ of protein. The dissociation constant ( $K_{\mathrm{D}}$ value) for [ $\left.{ }^{3} \mathrm{H}\right] \mathrm{DHA}$ binding was 11.1 $\pm 1.5 \mathrm{~nm}$. Depicted in the figure is a representative plot which was repeated three different times on different subcultures of the AtT'-20 cells.

$\left[{ }^{3} \mathrm{H}\right]$ DHA to AtT-20 cell membranes was inhibited in a dose-dependent manner by $d l$-propranolol with an apparent inhibitory constant of $10 \mathrm{~nm}$ (Fig. 2). The inactive stereoisomer of propranolol was much less potent in blocking $\left[{ }^{3} \mathrm{H}\right] \mathrm{DHA}$ binding (Fig. 2). Isoproterenol also inhibited $\left[{ }^{3} \mathrm{H}\right]$ DHA binding stereoselectively. The (-)isomer had an approximate inhibitory constant of $1 \mu \mathrm{M}$. Salmefamol, a potent $\beta_{2}$-adrenergic receptor agonist (Minneman et al., 1979a, b), could block at least $60 \%$ of specific $\left[{ }^{3} \mathrm{H}\right] \mathrm{DHA}$ binding at the highest concentration utilized. In contrast, the selective $\beta_{1}$-adrenergic receptor antagonist practolol (Dunlop and Shanks, 1968) did not alter $\left[{ }^{3} \mathrm{H}\right] \mathrm{DHA}$ binding. The $\alpha$-adrenergic antagonist phentolamine also did not block $\left[{ }^{3} \mathrm{H}\right] \mathrm{DHA}$ binding to AtT-20 cell membranes.

\section{Intracellular cAMP levels}

Exposure of AtT-20 cells to (-)-isoproterenol induced increases in intracellular cAMP content. Maximal effects of $(-)$-isoproterenol on cAMP formation appeared within 2 min of exposure (Fig. 3) and incubation of AtT-20 cells with (-)-isoproterenol for up to $60 \mathrm{~min}$ still produced significant increases in intracellular cAMP content. In the presence of a phosphodiesterase inhibitor (IBMX), (-)-isoproterenol stimulated cAMP formation in a dosedependent manner with an approximate half-maximal stimulating concentration of $50 \mathrm{~nm}$ (Fig. 4). $l$-Epinephrine and $l$-norepinephrine also stimulated cAMP formation in AtT-20 cells with approximate half-maximal concentra-

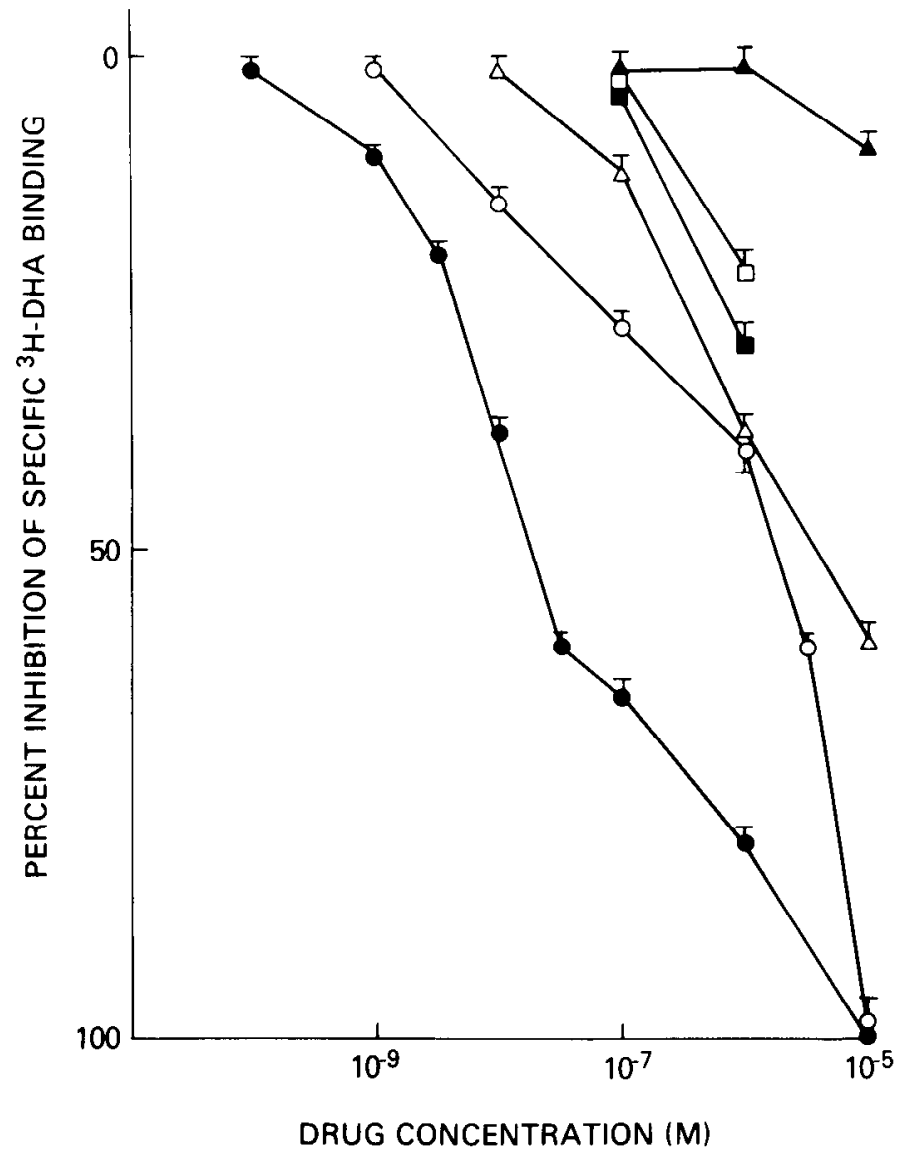

Figure 2. Inhibition of specific $\left[{ }^{3} \mathrm{H}\right] \mathrm{DHA}$ binding to AtT-20 cells. $\left[{ }^{3} \mathrm{H}\right] \mathrm{DHA}$ binding $(8 \mathrm{nM})$ was performed in the presence or absence of different competing ligands as described in the text. The amount of $\left[{ }^{3} \mathrm{H}\right] \mathrm{DHA}$ binding to tissue displaced by 10 $\mu \mathrm{M} d l$-propranolol was used to determine specific binding. The different competing ligands were $d l$-propranolol $(O), d$-propranolol $(\square),(-)$-isoproterenol $(O),(+)$-isoproterenol $(\square)$, salmefamol, $(\triangle)$, and practolol $(\Delta)$. Phentolamine at concentrations as high as $10 \mu \mathrm{M}$ did not alter [ $\left.{ }^{3} \mathrm{H}\right] \mathrm{DHA}$ binding. In no case did any of the displacing agents effect nonspecific binding. Each point represents the mean $\pm S E M$ of three experiments.

tions of $100 \mathrm{nM}$ and $1 \mu \mathrm{M}$, respectively (Fig. 4). The $l$ norepinephrine effect did not attain the maximal level of activation as observed with (-)-isoproterenol or $l$-epinephrine. Exposure of AtT-20 cells to the biologically inactive stereoisomer of norepinephrine did not affect intracellular cAMP content. The effect of $(-)$-isoproterenol was antagonized by $d l$-propranolol in a dose-dependent manner (Fig. 5). Salmefamol also stimulated cAMP formation in these cells (Table I).

\section{Secretion of ACTH-like immunoreactive material}

(-)-Isoproterenol induced a marked release of ACTH from AtT-20 cells. Elevation of hormone release occurred after 2 min of exposure to (-)-isoproterenol (Fig. 6) and a 2 to 4-fold increase in hormone release occurred following incubation of AtT-20 cells with (-)-isoproterenol for 10 to $60 \mathrm{~min}$. (-)-Isoproterenol facilitated the release of ACTH from AtT-20 cells in a dose-dependent fashion with a half-maximal stimulating concentration of approximately $1 \mathrm{nM}$ (Fig. 7). (+)-Isoproterenol did not affect 


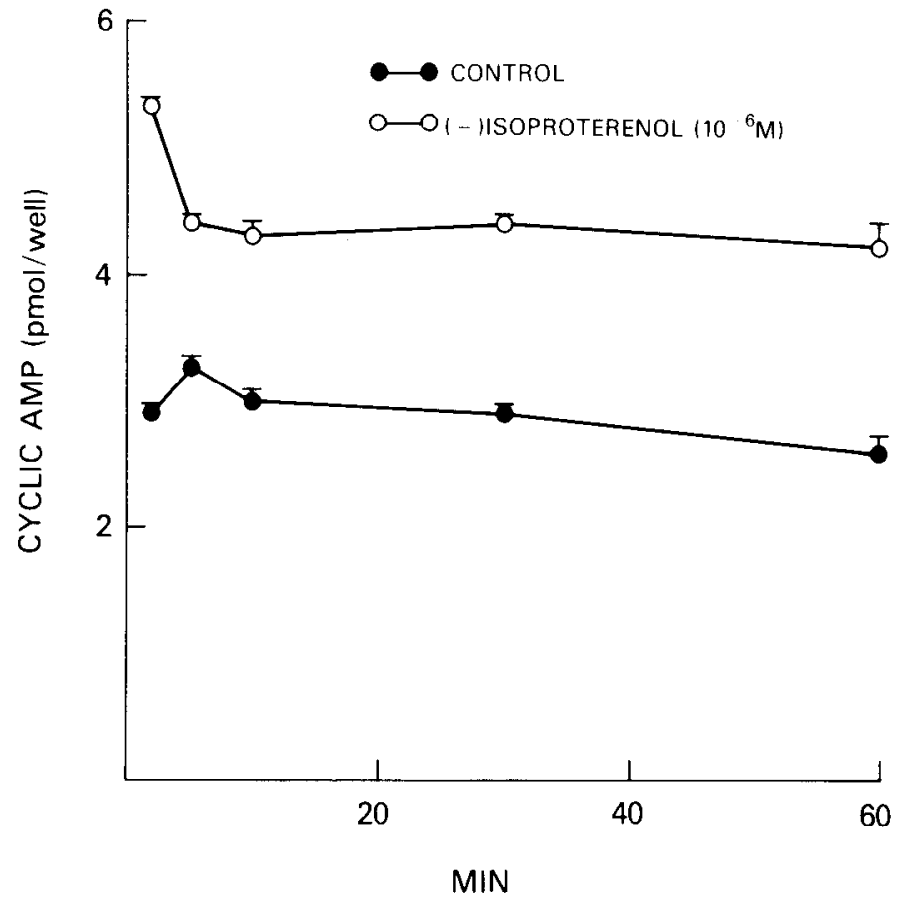

Figure 3. Time course of cAMP formation in At'T-20 cells. Intracellular cAMP formation was measured in the presence (O) and absence (O) of $1 \mu \mathrm{M}(\cdots)$-isoproterenol. In these experiments, the cells were equilibrated with medium containing DMEM and $2 \%$ fetal calf serum with $3 \mu \mathrm{g} / \mathrm{ml}$ of bacitracin for $1 \mathrm{hr}$. Then, similar medium with or without (-)-isoproterenol was added and the reaction was allowed to continue for varying periods of time. The reaction and cAMP detection were performed as described in the text. Each point represents the mean \pm SEM of values obtained in three separate cultures. The number of cells was the same in control and treated experiments.

hormone release at concentrations in which its biologically active stereoisomer produced maximal stimulation. Both $l$-epinephrine and $l$-norepinephrine increased ACTH secretion in a dose-dependent manner with the former substance being more potent. $d$-Norepinephrine did not alter hormone release at the concentrations tested. Salmefamol also increased ACTH secretion about 4-fold (Table I.)

l-Norepinephrine's stimulation of ACTH release was abolished by an equimolar concentration of $d l$-propranolol (Fig. 8). An equimolar concentration of the $\alpha$-adrenergic receptor antagonist phentolamine did not alter $l$ norepinephrine's facilitation of ACTH secretion, although a 10 -fold higher concentration caused a slight inhibitory effect.

(-)-Isoproterenol's stimulation of ACTH secretion from AtT-20 cells was blocked by $d l$-propranolol in a dose-dependent manner with an apparent inhibitory constant of $10 \mathrm{nM}$ (Fig. 9). $d l$-Propranolol $(1 \mu \mathrm{M})$ by itself did not alter ACTH release (Fig. 8). Phentolamine did not affect (-)-isoproterenol's stimulatory action (Fig. 9). Practolol, the $\beta_{1}$-receptor antagonist, also did not alter (-)-isoproterenol's effects on ACTH release (Fig. 9).

(-)-Isoproterenol's facilitation of $\Lambda \mathrm{CTH}$ release from

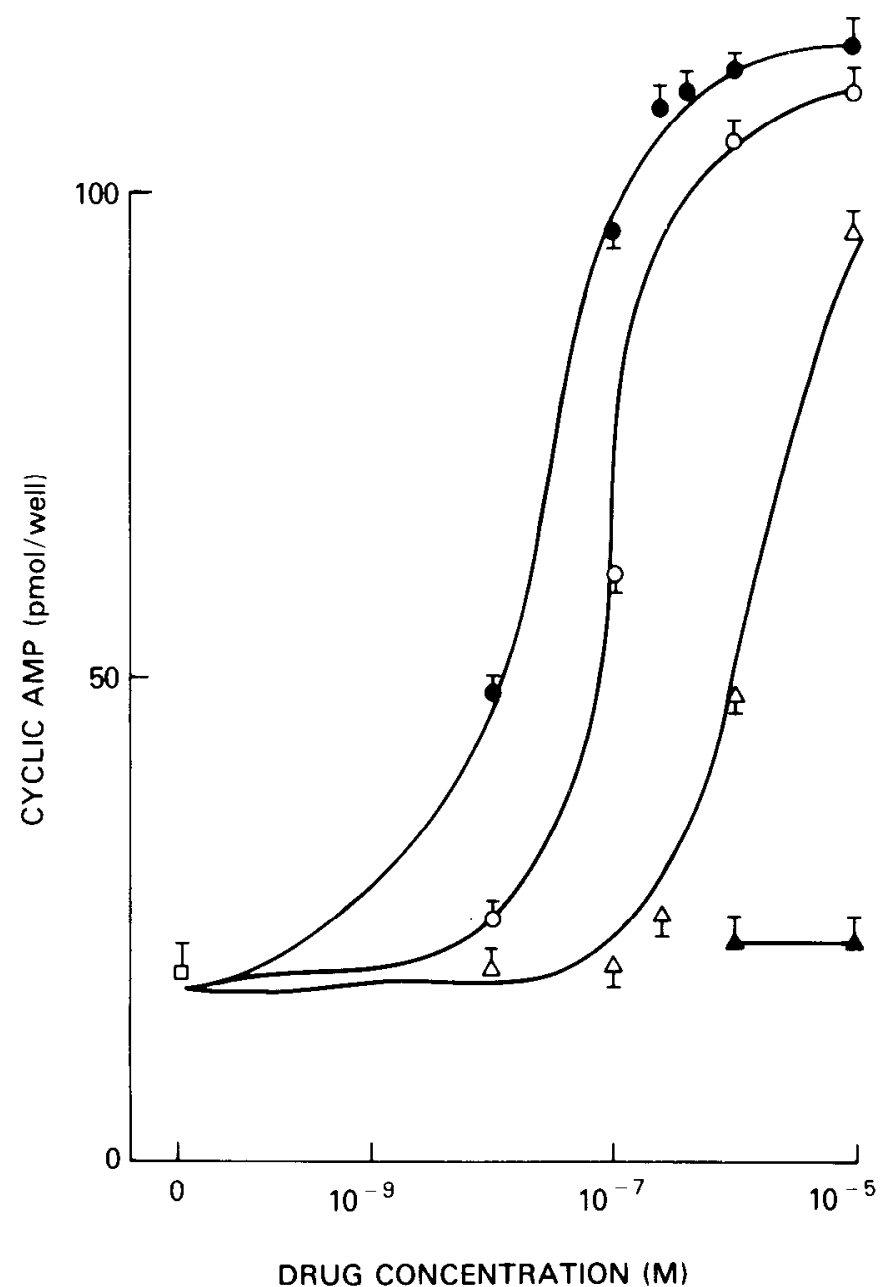

Figure 4. Stimulation of cAMP formation by various $\beta$ adrencrgic drugs. In these experiments, cells were equilibrated with medium containing DMEM, $2 \%$ fetal calf serum, and $3 \mu \mathrm{g} /$ $\mathrm{ml}$ of bacitracin for $1 \mathrm{hr}$. Then, fresh medium containing $5 \times$ $10^{-4} \mathrm{M}$ IBMX was added to the cells for $30 \mathrm{~min}$. After washing the cells, medium containing $5 \times 10^{-4} \mathrm{M}$ IBMX and the various test agents were added for $15 \mathrm{~min}$. The reaction was terminated and intracellular cAMP content was measured as described in the text. The effect of varying concentrations of $(-)$-isoproterenol $(\bigcirc), l$-epinephrine $(\circlearrowleft), l$-norepinephrine $(\Delta)$, and $d$-norepinephrine $(\Delta)$ were compared to untreated $(\square)$ cells. Each point represents the mean \pm SEM formation of cAMP in three to six separate cultures.

At T-20 cells was calcium dependent. In the presence of the calcium chelator, EGTA (1 mM), (-)-isoproterenol's stimulation of ACTH release ( $1 \mathrm{hr}$ incubation) was abolished (data not shown). The calcium-flux antagonist, verapamil $\left(10^{-6} \mathrm{M}\right)$, also reduced by $39 \%(-)$-isoproterenol's $\left(10^{-7} \mathrm{M}\right)$ stimulation of ACTH release $(p<0.05)$. Both EGTA and verapamil reduced basal ACTH release by approximately $20 \%$.

\section{Discussion}

Tumor cell lines have been used to study the characteristics, chemical properties, and biological responsiveness of a number of neurotransmitter and hormone re- 


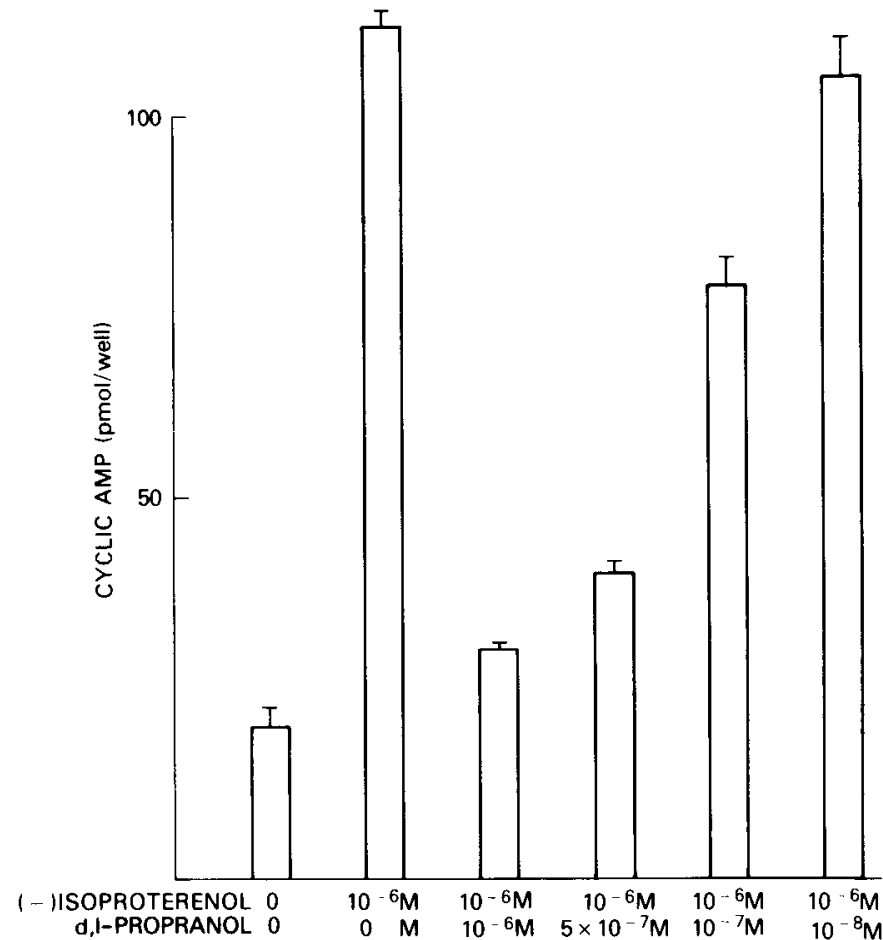

Figure 5. Inhibition of (-)-isoproterenol-stimulated cAMP formation in AtT-20 cells. Methods similar to those described in the legend to Figure 4 were employed. $d l$-Propranolol at different concentrations was co-applied with (-)-isoproterenol $(1 \mu \mathrm{M})$. The $\beta$-receptor antagonist had no effect on control cAMP formation by itself at a concentration of $1 \mu \mathrm{M}$. Each $b a r$ represents the mean \pm SEM formation of cAMP in three to six separate cultures.

ceptors. For example, in neuroblastoma cells the functional and biochemical interaction of opiate receptors with adenylate cyclase has been investigated extensively (Sharma et al., 1977; Blume et al., 1979). In C6 astrocytoma, the regulation (Su et al., 1978; Mallorga et al., 1980) of $\beta$-receptors as well as some of the mechanisms involved in their signal transduction across membranes have been elucidated (Hirata et al., 1980; Mallorga et al.,

TABLE I

Effect of salmefamol, a $\beta_{2}$-adrenergic agonist, on $A C T H$ release and cAMP formation

Cells were incubated with $\beta$-adrenergic agonists for $60 \mathrm{~min}$ and immunoreactive ACTH was determined as described under "Materials and Methods." In the cAMP studies, the cells were exposed to IBMX $\left(5 \times 10^{-4} \mathrm{M}\right)$ for $30 \mathrm{~min}$, the medium was removed, and the $\beta$-adrenergic agonists were then applied to the cells for $15 \mathrm{~min}$ in medium containing IBMX $\left(5 \times 10^{-4} \mathrm{M}\right)$. cAMP levels were determined as described in the text. ACTH release is expressed as nanograms of ACTH per well and cAMP levels are expressed as picomoles of cAMP formed per well. Controls are cells treated with medium lacking $\beta$-adrenergic agonist.

\begin{tabular}{lcc}
\hline & ACTH Release & cAMP Formation \\
\hline & $n g /$ well & pmol/well \\
Control & $10.5 \pm 0.7$ & $6.3 \pm 0.4$ \\
(-)-Isoproterenol $\left(10^{-6} \mathrm{M}\right)$ & $29.1 \pm 0.9$ & $67.0 \pm 0.2$ \\
Salmefamol $\left(10^{-6} \mathrm{M}\right)$ & $40.0 \pm 1.7$ & $61.3 \pm 3.1$ \\
\hline
\end{tabular}

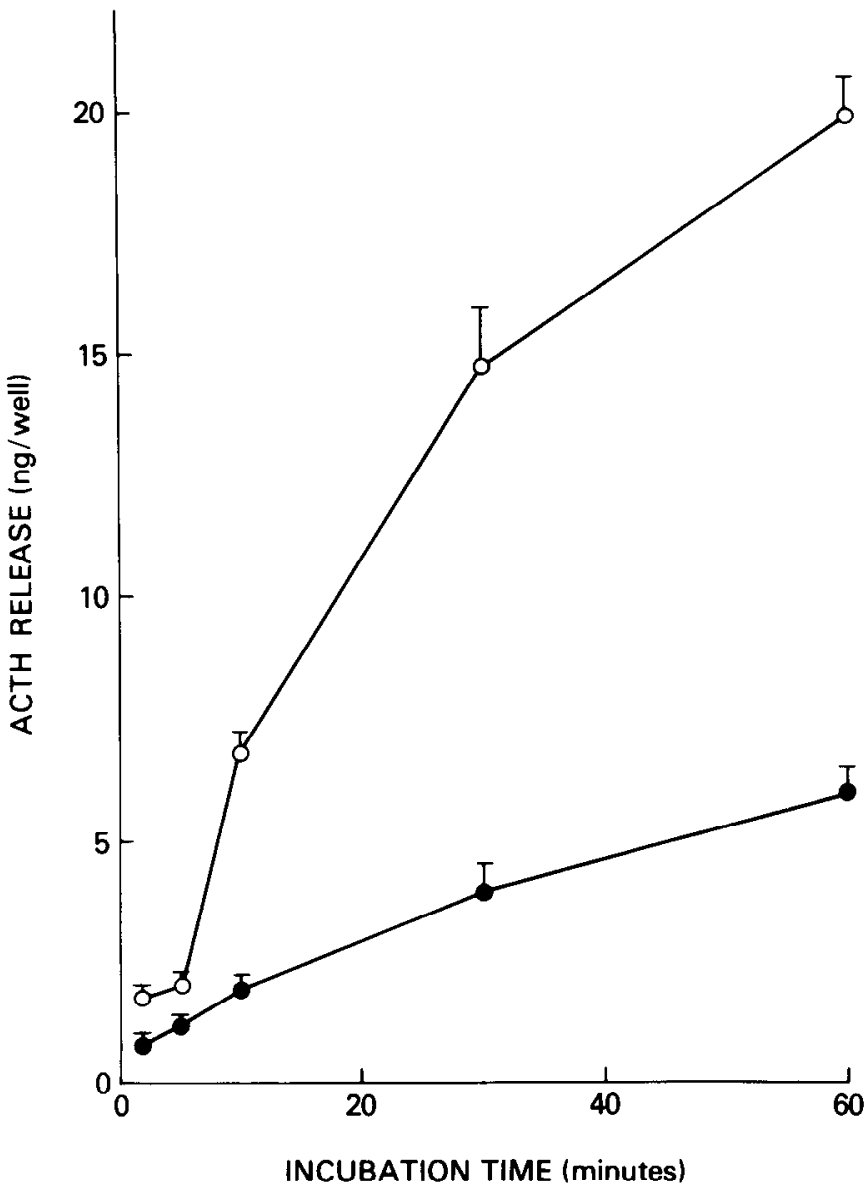

Figure 6. Time course of ACTH release from AtT-20 cells. Experiments were performed as described in the text in the presence $(O)$ or absence (O) of $1 \mu \mathrm{M}(-)$-isoproterenol. Each point represents the mean \pm SEM ACTH release from AtT-20 cells three separate cultures.

1980). Due to the homogeneity of the AtT-20 cell system, it was possible to study and correlate the binding of $\beta$ adrenergic drugs with cAMP formation and ACTH release in the same cell preparation.

$\beta$-Adrenergic receptors on AtT- 20 cells are stereoselective, have high affinity for $\beta$-receptor antagonists and agonists, low sensitivity for $\alpha$-adrenergic drugs, and are finite in number. $\beta$-Receptors in AtT-20 cells have equal and high affinity for two potent $\beta$-receptor blockers, dihydroalprenolol and $d l$-propranolol, but were insensitive to phentolamine, an $\alpha$-receptor antagonist. The greater ability of salmefamol to inhibit $\left[{ }^{3} \mathrm{H}\right] \mathrm{DHA}$ binding than practolol strongly suggests the presence of $\beta_{2}$-adrenergic receptors. $\beta$-Adrenergic receptors with similar characteristics are found in the cerebellum (Minneman et al., 1979b), lung (Minneman et al., 1979a), and intermediate lobe of the pituitary (Cote et al., 1980; Munemura et al., 1980).

Activation of $\beta$-receptors increases the formation of cAMP from ATP (Daly, 1977) in tissues including AtT20 cells. ( - -)-Isoproterenol stimulated intracellular cAMP formation in AtT-20 cells at a half-maximal effective concentration similar to that found in other tissues $(\mathrm{Mu}-$ 


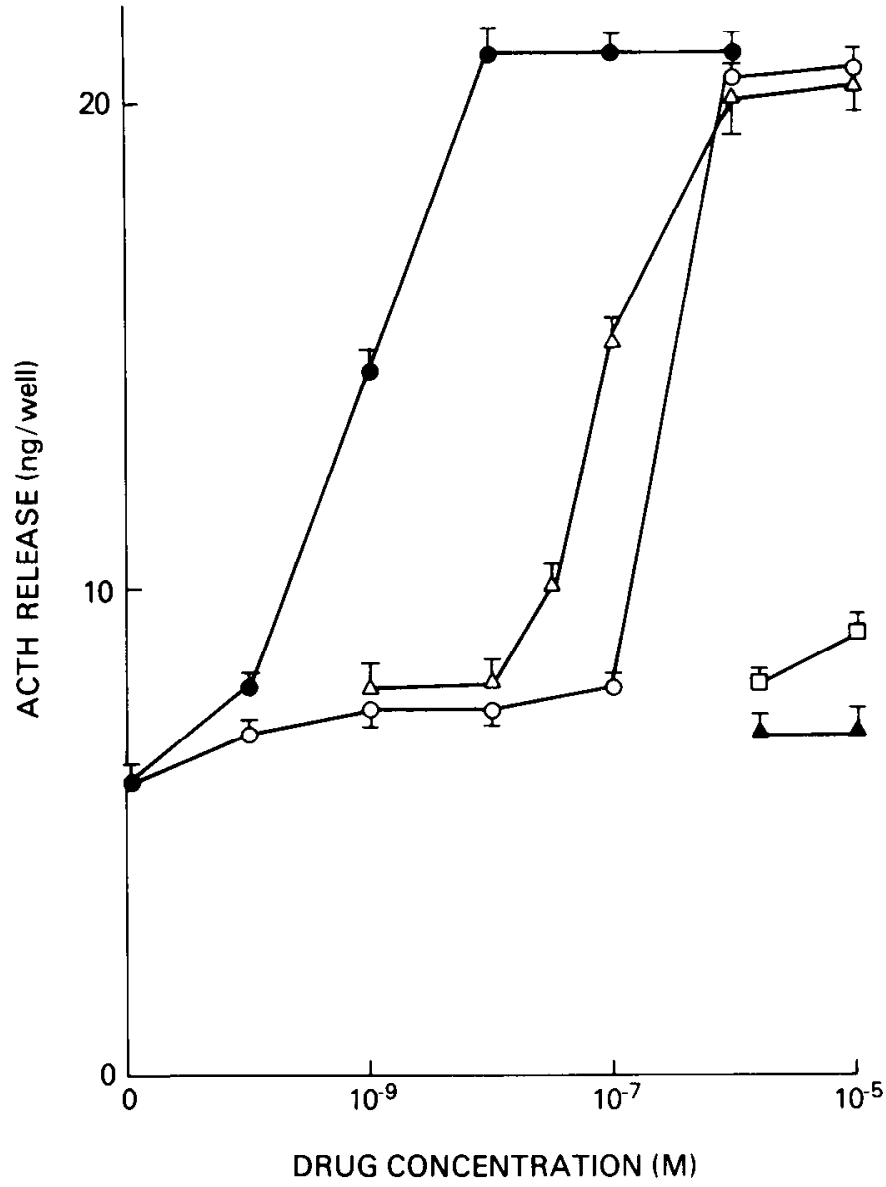

Figure 7. Stimulation of ACTH release from At'T-20 cells by different $\beta$-adrenergic agents. Experiments were performed as described in the text. Cells were incubated with varying concentrations of $(-)$-isoproterenol $(\mathbf{O}),(+)$-isoproterenol $(\square), l$ epinephrine $(\Delta), l$-norepinephrine $(O)$ or $d$-norepinephrine (A). Each point represents the mean \pm SEM ACTH release from AtT-20 cells in six to nine different cultures.

nemura et al., 1980). This effect was blocked by $d l$ propranolol in a concentration-dependent manner. 'The relative order of potency of the $\beta$-adrenergic agonists in stimulating cAMP formation in AtT-20 cells was (-)isoproterenol $>l$-epinephrine $>l$-norepinephrine, a characteristic profile of $\beta_{2}$-receptor subtype (Furchgott, 1972). The selective $\beta_{2}$-receptor agonist, salmefamol, also increased cAMP formation in these cells. All of these observations indicate that cAMP synthesis in AtT-20 cells is mediated in part by $\beta_{2}$-adrenergic receptors.

$(-)$-Isoproterenol induced a potent and stereoselective stimulation of ACTH release which was calcium dependent and blocked by $d l$-propranolol. The maximal stimulation of cAMP formation by (-)-isoproterenol preceded the appearance of the maximal changes in ACTH release. This suggests that stimulation of cAMP formation by $\beta$-receptor agonists leads to release of $\mathrm{ACTH}$. The potency of $(-)$-isoproterenol in stimulating $\mathrm{ACTH}$ release was greater than its potency to increase cAMP formation or to inhibit $\left[{ }^{3} \mathrm{H}\right] \mathrm{DHA}$ binding. The conditions used in each of these studies are different and could affect the apparent affinity of $\beta$-receptors for $(-)$-isoproterenol or the efficacy of this agonist to produce its different biolog- ical effects. The affinity of the $\beta$-receptors on AtT-20 cells for $d l$-propranolol was similar in each preparation and the relative order of $\beta$-receptor agonist potencies in affecting cAMP formation and ACTH secretion were the same. Munemura et al. (1980) observed a 75 -fold greater potency for (-)-isoproterenol stimulation of $\alpha$-melanocyte-stimulating hormone $(\alpha-\mathrm{MSH})$ release than cAMP formation in dispersed neural intermediate lobe cells. These authors have argued that only small increases in intracellular cAMP levels may be needed to induce maximal changes in $\alpha$-MSH secretion. A similar hypothesis may explain the observations of the present study.

The $\beta$-receptors mediating (-)-isoproterenol's effects on ACTH release, like those regulating cAMP synthesis, are of the $\beta_{2}$-subtype. This is evident from the ability of salmefamol to stimulate ACTH secretion as well as the greater potency of $l$-epinephrine than $l$-norepinephrine to induce ACTH secretion. The binding, cyclic nucleotide formation, and ACTH release data all confirm the presence of functional $\beta_{2}$-adrenergic receptors on AtT-20 cells.

Giguere et al. (1981) have shown that (-)-isoproterenol stimulates ACTH secretion from primary cultures of dispersed pituitary cells, although the $\beta$-adrenergic agonist was several orders of magnitude less potent than we observed in the AtT-20 cells. The different potencies observed in the two preparations may be due to a number of factors. For example, primary cultures are heterogeneous in cell type and other effects may be induced by $(-)$-isoproterenol, which could mask its stimulation of ACTH release. In the study with primary cultures (Giguere et al., 1981). (-)-isoproterenol was exposed to the cells for $4 \mathrm{hr}$. Relatively long exposure periods have been reported to induce a desensitization of $\beta$-receptors in astrocytoma (Su et al., 1978, 1980; Mallorga et al., 1980), S49 lymphoma cells (Su et al., 1980), and frog erythrocytes (Wessels et al., 1979). This densensitization process involves an uncoupling of the $\beta$-receptor from adenylate cyclase. We observed that exposure of AtT-20 cells to $(-)$-isoproterenol for $4 \mathrm{hr}$ greatly reduced the ability of the $\beta$-receptor agonist to stimulate cAMP formation (unpublished data). Since (-)-isoproterenol seems to regulate ACTH release through a cAMP-dependent mechanism, the uncoupling of the $\beta$-receptor-adenylate cyclase system in corticotrophs, as occurs after 4-hr exposure to $(-)$-isoproterenol, may explain the relative insensitivity of (-)-isoproterenol to stimulate ACTH secretion as previously reported (Giguere et al., 1981).

Glucocorticoids are known to inhibit ACTH release and synthesis from anterior pituitary cells (Jones, 1978; Sabol, 1980). Furthermore, these agents block CRF's stimulation of ACTH release both from primary cultures of anterior pituitary cells (Giguere et al., 1982b) and AtT20 cells (Hook et al., 1982). Berkenbosch et al. (1981) have also observed in anesthetized rats that $l$-epinephrine can increase plasma ACTH levels by acting through $\beta$ receptors and that dexamethasone antagonizes this process. In these studies, $l$-epinephrine may have stimulated $\mathrm{ACTH}$ release from the anterior pituitary either by acting directly at the adenohypophysis or by central mechanisms. We have observed that dexamethasone reduces $(-)$-isoproterenol's facilitation of ACTH secretion from 


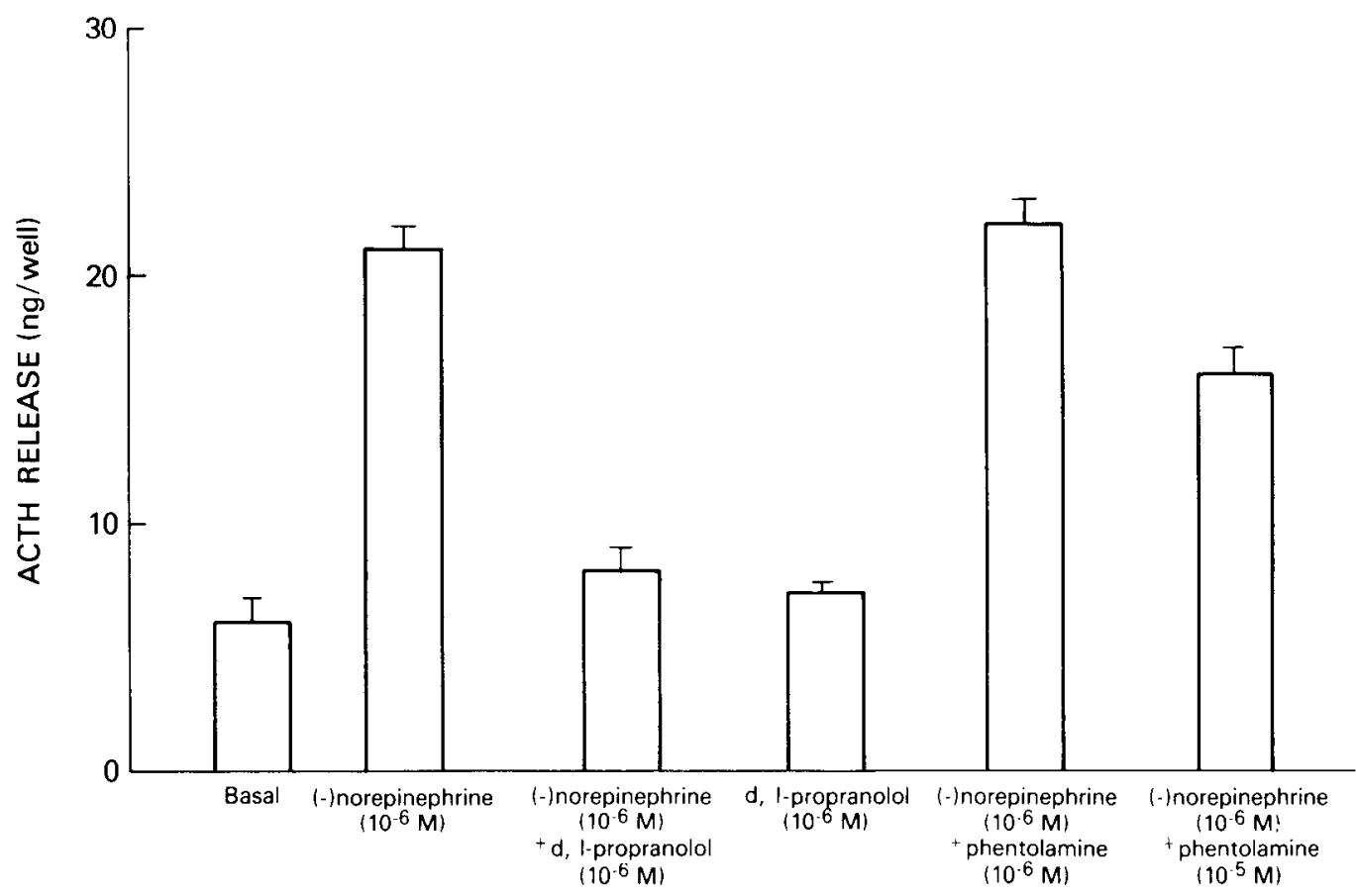

Figure 8. Inhibition of $l$-norepinephrine-stimulated ACTH release from AtT-20 cells. Experiments wer performed as described in the text. $l$-Norepinephrine was either co-applied with $d l$-propranolol or phentolamine. Each bar represents the mean $\pm \mathrm{SEM}$ $\mathrm{ACTH}$ release from AtT-20 cells in three separate cultures.

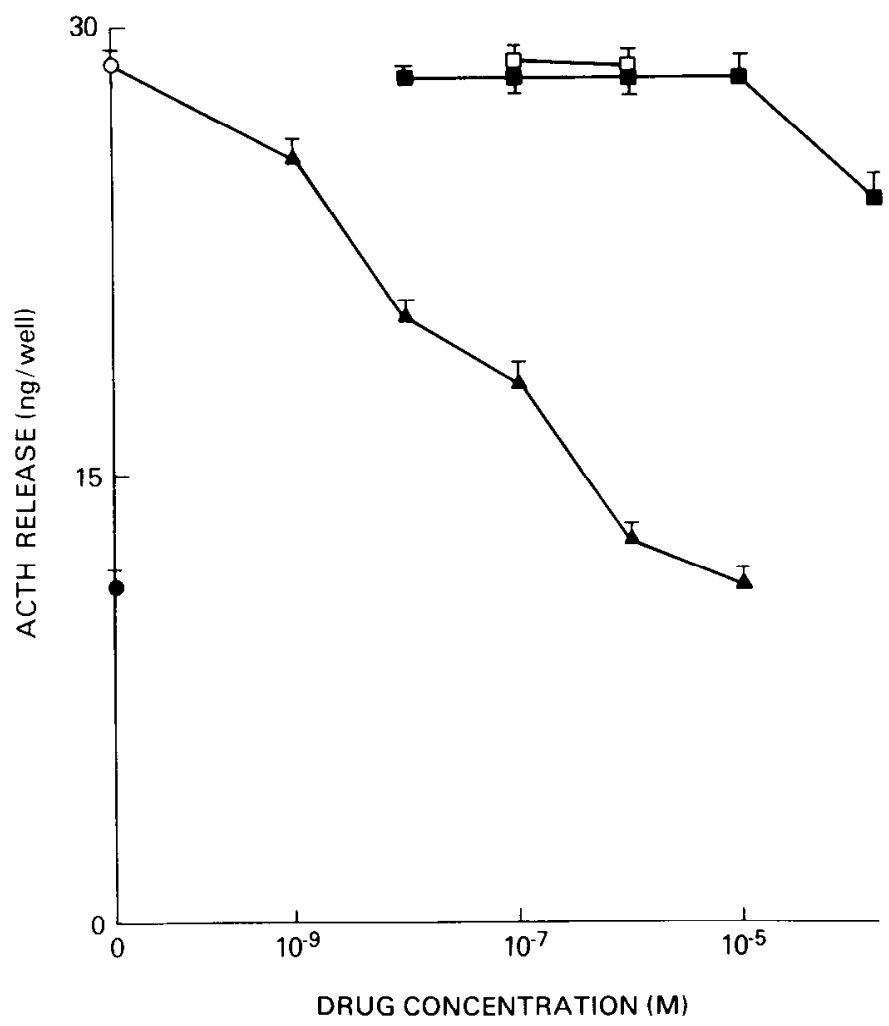

Figure 9. Inhibition of (-)-isoproterenol-stimulated ACTH release from AtT-20 cells. Fxperiments were performed as described in the text. Cells were treated with (-)-isoproterenol $\left(10^{-6} \mathrm{M}\right)(\mathrm{O})$ in the presence of varying concentrations of either $d l$-propranolol $(\boldsymbol{\Delta})$, practolol $(\square)$, or phentolamine ( $\square$ ). Basal release (O) is also displayed. Each point represents the mean \pm SEM ACTH release from AtT-20 cells in three separate cultures.
AtT-20 cells in a dose- and time-dependent fashion (unpublished data), suggesting that circulating catecholamines may directly regulate corticotroph activity. However, these findings do not exclude a central mechanism of catecholamine regulation of ACTH secretion. In any case, there exists a parallelism between the in vivo and in vitro ability of $\beta$-receptor agonists to control the release of ACTH from the anterior pituitary.

We have also observed that in addition to catecholamines, ACTH release from AtT-20 cells is increased by CRF (Hook et al., 1982) and vasoactive intestinal peptide (unpublished data). The effects of all of these hormones are blocked by somatostatin and dexamethasone (unpublished data). These data suggest that ACTH secretion from $\Lambda \mathrm{t} T-20$ cells is under multi-receptor control and involves complex intracellular interactions.

\section{References}

Allen, R. E., E. Herbert, M. Hinman, H. Shibuya, and C. Pert (1978) Coordinate control of corticotropin, $\beta$-lipotropin and $\beta$-endorphin release in mouse pituitary cell cultures. Proc. Natl. Acad. Sci. U. S. A. 75: 4972-4976.

Berkenbosch, F., I. Vermes, R. Binnekade, and F. J. H. Tilders (1981) $\beta$-Adrenergic stimulation induces an increase of the plasma levels of immunoreactive $\alpha$-MSH, $\beta$-endorphin, ACTH and of corticosterone. Life Sci. 29: 2249-2256.

Blume, A. J., D. Lichtshtein, and G. Boone (1979) Coupling of opiate receptors to adenylate cyclase: Requirement for $\mathrm{Na}^{+}$ and GTP. Proc. Natl. Acad. Sci. U. S. A. 76: 5626-5630.

Cote, T., M. Munemura, R. Eskay, and J. Kebabian (1980) Biochemical identification of the $\beta$-adrenoceptor and evidence for the involvement of an adenosine $3^{\prime}, 5^{\prime}$-monophosphate system in the $\beta$-adrenergic induced release of $\alpha$-melanocyte-stimulating hormone in the intermediate lobe of the rat pituitary gland. Endocrinology 107: 108-113. 
Daly, J. (1977) Cyclic Nucleotides in the Nervous System, Plenum Press, New York.

Dunlop, D., and R. Shanks (1968) Selective blockade of adrenoceptive $\beta$-receptors in the heart. Br. J. Pharmacol. 32: 201218.

Eipper, B. A., and R. F. Mains (1980) Structure and biosynthesis of pro-adrenocorticotropin/endorphin and related peptides. Endocrinol. Rev. 1: 1-27.

Furchgott, R. (1972) The classification of adrenoceptors. In Catecholamines, H. Blaschko and E. Muscholl, eds., pp. 283335 , Springer-Verlag, Berlin.

Giguere, V., J. Cote, and F. Labrie (1981) Characteristics of the $\alpha_{1}$-adrenergic stimulation of adrenocorticotropin secretion in rat anterior pituitary cells. Endocrinulogy 109: 757-763.

Giguere, V., J. Cote, and F. Labrie (1982a) Specific inhibition by glucocorticoids of the $\alpha_{1}$-adrenergic stimulation of adrenocorticotropin release in rat anterior pituitary cells. Endocrinology 110: 1225-1230.

Giguere, V., F. Labrie, J. Cote, D. Coy, J. Sueiras-Diaz, and A. Schally (1982b) Stimulation of cyclic-AMP accumulation and corticotropin release by synthetic ovine corticotropin-releasing factor in rat anterior pituitary cells: Site of glucocorticoid action. Proc. Natl. Acad. Sci. U. S. A. 79: 3466-3469.

Hirata, F., J. F. Tallman, R. C. Henneberry, P. Mallorga, W. J. Strittmatter, and J. Axelrod (1980) Regulation of $\beta$-adrenergic receptors by phospholipid methylation. In Receptors for Neurotransmitter and Peptide Hormones, G. Pepeu, M. J. Kuhur, and S. J. Enna, eds., pp. 91-97, Raven Press, New York.

Hook, V. Y. H., S. Heisler, S. Sabol, and J. Axelrod (1982) Corticotropin releasing factor stimulates adrenocorticotropin and $\beta$-endorphin release from AtT-20 mouse pituitary tumor cells. Biochem. Biophys. Res. Commun. 106: 1364-1371.

Jones, M. T. (1978) Control of corticotropin (ACTH) secretion. In The Endocrine Hypothalamus, S. L. Jeffcoate and J. S. M. Hutchinson, eds., pp. 386-418, Academic Press, Inc., New York.

Mains, R., and B. Eipper (1976) Biosynthesis of adrenocorticotropic hormone in mouse pituitary tumor cells. J. Biol. Chem. 251: 4115-4120.

Mains, R., and B. Eipper (1981) Coordinate, equimolar secretion of smaller peptide products derived from pro-ACTH/endorphin by mouse pituitary tumor cells. J. Cell Biol. 89: 21-28.

Mallorga, P., J. F. Tallman, R. C. Henneberry, F. Hirata, W. J. Strittmatter, and J. Axelrod (1980) Mepacrine blocks $\beta$-adrenergic agonist-induced desensitization in astrocytoma cells. Proc. Natl. Acad. Sci. U. S. A. 77: 1341-1345.

Minneman, K., L. Hegstrand, and P. B. Molinoff (1979a) The pharmacological specificity of $\beta-1$ and $\beta-2$ adrenergic receptors in rat heart and lung in vitro. Mol. Pharmacol. 16: 2133 .

Minneman, K. P., L. Hegstrand, and P. B. Molinoff (1979b) Simultaneous determination of $\beta_{1}$ and $\beta_{2}$-adrenergic receptors in tissues containing both receptor subtypes. Mol. Phar- macol. 16: $34-46$.

Munemura, M., R. Eskay, and J. Kebabian (1980) Release of $\alpha$-melanocyte-stimulating hormone from dispersed cells of the intermediate lobe of the rat pituitary gland: Involvement of the catecholamines and adenosine $3^{\prime}, 5^{\prime}$-monophosphate. Endocrinology 106: 1795-1800.

Rivier, C., M. Brownstein, J. Spiess, J. Rivier, and W. Vale (1982) In vivo corticotropin-releasing factor-induced secretion of adenocorticotropin, $\beta$-endorphin and corticosterone. Endocrinology 110: 272-278.

Roberts, J. L., and E. Herbert (1977a) Characterization of a common precursor to corticotropin and $\beta$-lipotropin: Cellfree synthesis of the precursor and identification of corticotropin peptides in the molecule. Proc. Natl. Acad. Sci. U. S. A. 74: $4826-4830$.

Roberts, J. L., and E. Herbert (1977b) Characterization of a common precursor to corticotropin and $\beta$-lipotropin: Identification of $\beta$-lipotropin peptides and their arrangement relative to corticotropin in the precursor synthesized in a cellfree system. Proc. Natl. Acad. Sci. U. S. A. 74: 5300-5304.

Roberts, J. L., M. Phillips, P. A. Rosa, and E. Herbert (1978) Steps involved in the processing of common precursor forms of adrenocorticotropin and endorphin in cultures of mouse pituitary cells. Biochemistry 17: 3609-3618.

Sabol, S. (1980) Storage and secretion of $\beta$-endorphin and related peptides by mouse pituitary tumor cells: Regulation by glucocorticoids. Arch. Biochem. Biophys. 203: 37-48.

Sharma, S. K., W. Klee, and M. Nirenberg (1977) Opiatedependent modulation of adenylate cyclase. Proc. Natl. Acad. Sci. U. S. A. 74: 3365-3369.

Spiess, J., J. Rivier, C. Rivier, and W. Vale (1981) Primary structure of corticotropin-releasing factor from ovine hypothalamus. Proc. Natl. Acad. Sci. U. S. A. 78: 6517-6521.

Su, Y. -F., T. K. Harden, and J. Perkins (1978) Isoproterenolinduced densensitization of adenylate cyclase in human astrocytoma cells. J. Biol. Chem. 254: 38-41.

Su, Y. -F., T. K. Harden, and J. Perkins (1980) Catecholaminespecific desensitization of adenylate cyclase. J. Biol. Chem. 255: 7410-7419.

Tilders, F. J. H., F. Berkenbosch, and P. Smelik (1982) Adrenergic mechanisms involved in the control of pituitary-adrenal activity in the rat: $\mathrm{A} \beta$-adrenergic stimulatory mechanism. Endocrinology 110: 114-121.

Vale, W., and C. Rivier (1977) Substances modulating the secretion of ACTH by cultured anterior pituitary cells. Fed. Proc. 36: 2094-2099.

Vale, W., J. Spiess, C. Rivier, and J. Rivier (1981) Characterization of a 41-residue ovine hypothalamic peptide that stimulates secretion of corticotropin and $\beta$-endorphin. Science 213: 1394-1397.

Wessels, M., D. Mullikin, and R. J. Lefkowitz (1979) Selective alteration in high affinity agonist binding: A mechanism of $\beta$-adrenergic receptor desensitization. Mol. Pharmacol. 16: 10-20. 